論文
세계 LCC 비즈니스 모델의 전략적 변화 연구 및 국내 LCC 산업 관련 시사점 도출(세계 주요 $\mathrm{LCC}$ 사례를 중심으로)
김상도*, 김기웅**, 최건희***

\title{
Study on the strategic changes of the world LCC business models and their implications to Korean LCC industry(A Case Study of the world's major LCCs)
}

\author{
Sang Do Kim*, Kee Woong Kim**, Kun Hee Choi***
}

\begin{abstract}
As the price competition between airlines became increasingly intensified, due to increased participation of low-cost carriers in the air transport industry and the continued deregulation of international air transport, each airline has introduced various management techniques for securing international competitiveness and operational efficiency in order to cope with the uncertainty in air transport industry. The world leading LCCs, such as Ryan air, easyJet and Southwest, have changed their traditional business models by increasing operation to primary airports, diversifying operating routes, making strategic alliances with FSCs or other LCCs, increasing the operations on the mid or long distance routes, expanding ancillary revenues, etc. As Korea's air transport industry is confronting with intense competition, our LCCs are requested to adjust to this new challenging situation. As the world leading LCCs did, Korean LCCs are recommended to adopt new business models such as restructuring of the air transport industry through M\&A, operating more flexibly in terms of frequency or route, launching of services to primary airports, making strategic alliances with foreign FSCs, developing of 4 th or 6 th traffic demands, etc.
\end{abstract}

Key Words : LCC(저비용항공사), Business Model(비즈니스 모델), Air Transport Industry(항 공운송산업)

I. 서 론

저비용항공사의 항공운송산업 참여 증대와 세 계 항공운송 관련 규제 완화가 지속됨에 따라, 항공사 간 가격경쟁이 점차 심화되어 가고, 각 항공사들은 항공산업의 불확실성에 대응하기 위

2013년 08월 27일 접수 2013년 09월 23일 심사완료 논문심사일 (2013.08.30, 1차), (2013.09.17, 2차)

* 국토교통부 부이사관

** 한국항공대학교 경영학과 교수

*** 인천국제공항공사 정보기획팀 대리 연락저자, E-mail : webdesk@empal.com 인천광역시 중구 공항로 424 번길 47
해, 국제경쟁력 및 운영 효율성 확보를 위한 경 영기법을 도입하고 있다.

특히 자유화와 개방화 속에서 시장참여의 확대 로 항공사 간 경쟁이 날로 심화되어 감에 따라 이용객들의 효익은 점차 증대되어지는 반면 항공 사들의 수익성은 저하되어 가고 있으며, 이러한 위기를 극복하기 위해 항공사들은 비즈니스 모델 의 변화를 추진함으로써 국제경쟁력 확보 및 신 규시장개발을 위해 노력하고 있다. 광범위한 노 선망으로 글로벌 네트워크를 형성한 FSC(Full Service Carrier, 대형 항공사)는 대형화를 통해서 지속가능 전략을 추진하고 있으며 판매비와 운영 비용을 최소화하는 저비용구조로 운항 범위가 제 
한적인 LCC(Low Cost Carrier, 저비용항공사)의 경우에도 변화에 대응하기 위해 새로운 비즈니스 모델을 추진해 가고 있다. 본 연구에서는 세계적 으로 LCC가 가장 발달한 미국과 유럽 내 주요 LCC 항공사의 비즈니스 모델 변화에 대한 사례 를 통해 세계 주요 $\mathrm{LCC}$ 의 대응전략을 면밀히 살 펴보고자 하였다. 특히 비즈니스 모델의 성장한 계 및 변화와 관련하여 노선집중화와 주요 공항 의 사용, 노선 선택 및 운항횟수, LCC허브화, 운 항 거리 증가, 부가수익 증대 등의 측면에서 주 요 LCC항공사들을 살펴보았으며, 향후 국내 $\mathrm{LCC}$ 들에게 발생할 수 있는 환경변화 및 이에 대 응하기 위한 전략 관련 시사점을 도출하고자 하 였다.

\section{II. 본 론}

\subsection{LCC 비즈니스 모델}

\subsubsection{LCC 개념}

LCC는 low cost carrier, low cost airlines이라 고 할 수 있으며, 일반적으로 $\mathrm{CAPA}(2002)$ 의 보 고서에서는 '저비용항공사에 대해 명확한 정의를 내릴 수 없고 지역이나 시장에 따라 구조와 목적 을 달리하는 카멜레온과 같은 항공사라는 표현 을 하였다. 전통적인 LCC 비즈니스 모델은 저비 용구조 기반 비즈니스 모델을 통해 여러 부문에 서 FSC와 차별성을 이루고 있다고 볼 수 있다. Thomas(2002)는 저비용항공사의 특징을 단거리 운항 및 지점간 운송(Point to Point), 부가서비스 미제공(No frill service), 전자항공권 활용 및 유 통채널최소화, 마일리지 프로그램 미시행 등으로 구분하여 살펴보았으며, Campbell \& Kingsley(2002)는 유럽과 미국의 대표적인 저가 항공사 Ryanair, Southwest 의 경우 FSC 대비 ASK당 소요비용이 약50\% 소요되는 특징을 보였 다고 보았다. 그리고 Franke(2004)는 중소형 지방 공항 이용 및 제한된 서비스, 단순한 조직 운영 등을 저가항공사의 주요 전략적 특징으로 보았 다. 이처럼 LCC는 항공기 운영 효율성 향상을 위해 FSC의 허브앤스포크(Hub \& Spoke)전략에 서 벗어나 유휴시간 최소화, 항공기 가동률 최대 화를 지향하는 지점 간 수송(Point to Point)전략 을 기반으로 단거리 운항에 가급적 많은 항공노 선을 제공하고, 항공기 기종 단일화를 통한 관리 비용 축소 및 불필요한 서비스의 과감한 배제 등
을 추진하고 있다. 또한 주요 공항이 아닌 2차 공항(Secondary Airport)을 이용함으로써 효율적 으로 슬롯을 확보하여 항공기 운항스케줄을 운영 하고, 주요 기존 공항에서 이루어지는 포화 상태 의 공항혼잡을 피함으로써 운항 제반 비용을 절 감하고 있다. Doganis(2010), Sterzenbach et $\mathrm{al}(2009)$ 도 LCC 비즈니스 모델과 관련하여 지점 간 수송 (Point-to-Point) 및 기종단일화(Single Aircraft type, A320 or B737 family), 제2공항으 로 불리는 외곽 공항의 사용, 단일편도운임제공 및 단일 객실 등급 (Mono Class), 직접 판매 (항 공사 홈페이지 등 활용) 등과 같은 특징으로 $\mathrm{LCC}$ 를 설명하였다. 저가항공사는 이러한 전략적 특징을 기반으로 공항사용료, 부가수익, 용량 활 용률, 운항지연율, 기재회전율 등의 측면에서 경 쟁력을 지니고 있다.(ELFAA, 2004) 이러한 특징 의 LCC를 주요 지역별로 살펴보면 유럽과 미국 의 LCC순위는 <Table 1 >과 같이 나타났으며, 미 국에서의 LCC는 Southwest를 시작으로 새로운 수요 창출과 시장 개척에 초점을 맞추고 성장하 였고 유럽에서는 1990년대 중반부터 LCC의 진입 과 동시에, 빠른 속도로 시장 점유율 확대가 이 루어졌다고 볼 수 있다. 유럽시장에서 Ryanair와 Easyjet이 성공적으로 자리 잡을 수 있었던 요인 은 $\mathrm{EU}$ 에 따른 규제완화에 기인한다고 볼 수 있 다.(Francis, Humphreys, Ison \&Aicken, 2006). 최근에는 LCC 비즈니스 모델이 다양한 형태로 이루어지고 있으며, LCC 그룹 내에서도 시장 변 화에 따라 세분화된 형태의 비즈니스 모델이 나 타나고 있다.(Franke and John, 2011; Taneja, 2010)

Table 1. 유럽과 미국의 LCC 순위 (ASKs 기준)

\begin{tabular}{|c|c|c|c|}
\hline 유럽 LCC & ASK & 미국LCC & ASK \\
\hline Ryanair & 2,777 & Southwest & 3,263 \\
\hline Easyjet & 1,669 & JetBlue & 1,378 \\
\hline
\end{tabular}

\subsubsection{LCC 유형}

LCC는 독자적으로 저비용 비즈니스 모델을 구 축한 경우, 기존의 항공사가 $\mathrm{LCC}$ 로 체제전환을 한 경우, $\mathrm{FSC}$ 가 $\mathrm{LCC}$ 를 설립한 경우로 분류할 수 있으며, 첫 번째는 미국의 Southwest가 대표 적이고, 체제 전환의 대표적인 사례는 영국의 Ryanair를 들 수 있으며, FSC가 설립한 $\mathrm{LCC}$ 는 미국 United 항공사의 Ted가 대표적이라고 할 
수 있다. 과거 미국과 유럽에서 $\mathrm{FSC}$ 가 설립한 $\mathrm{LCC}$ 의 경우, 저가 및 단일기종 등의 형식적 특 징만을 도입함으로써 LCC만의 경쟁력을 갖추지 못한 사례가 나타났으나, 최근에는 아태 지역에 서 $\mathrm{FSC}$ 의 자회사 또는 사업부를 통해 $\mathrm{LCC}$ 를 운 영하고자 하는 시도가 이루어지고 있다(CAPA, 2012)

\subsubsection{LCC 성장}

최근 $\mathrm{LCC}$ 의 성장에 대해서 많은 사례 연구가 이루어져 왔으며, 대부분의 연구에서 LCC는 저 가운용구조를 기반으로 FSC대비 높은 가격경쟁 력을 확보함으로써 운임에 탄력적인 여행객들에 대한 신규 항공 수요를 창출한 것으로 나타났다 (김제철, 2004).

특히, Ryanair의 진출로 91년 211만 명에 그치 던 런던-더블린 노선의 총여객수요가 07년 427만 명으로 증가한 것은 신규 항공 수요 창출의 대표 적인 사례라고 할 수 있다. 저비용항공사의 항공 운송시장 출범과 확대는 전 세계적인 추세로서, 국내시장에서도 지속적인 성장이 이루어지고 있 으며 이와 관련하여 많은 연구가 이루어졌다. 저 가항공사에 대한 성공요인, SWOT분석, 포지셔닝 전략, 경쟁력 제고방안, 정책적 제언, 중거리노선 의 필요성, 전략적인 협력 필요성 등을 포함하여 다루고 있는 연구 등이 그 예라고 할 수 있을 것 이다.(최경훈, 2008; 양용석, 2005; 최휴종, 2010; 한대로, 2010, 양용석, 2011, 서선, 2008, 육진영, 2012) 유럽과 미주지역 저가항공시장의 경우, 급 속한 성장 이후 다시 변화가 이루어지고 있는데 유럽시장 내 저가항공사의 연결방식에 있어 중장 거리 노선 확대로 지역별 연결이 늘어나는 것이 그 대표적인 예라고 할 수 있다.(Garriga, 2007) 미국에서 시작된 규제완화로 시장진입이 용이해 짐에 따라 점차 경쟁이 심화되고 있으며 지속적 으로 국제경쟁력을 확보하기 위해 LCC는 기존 비즈니스 모델을 변경하여 LCC와 FSC의 특징을 결합한 하이브리드 형태의 LCC를 많이 운영하고 있다. Jetblue airways가 중장거리 운항노선을 운 영하고 장거리-단거리 운항 관련 혼합시스템을 운영하는 것도 그러한 이유 때문이다. (Gittell, 2003) 이로 인해 항공시장에서 더 이상 LCC와 $\mathrm{FSC}$ 로 구별하는 것이 점차 의미가 없어지게 되 었다(Gui Lohmann \& Koo, 2013). 과거 공격적 인 시장 운용 및 운임경쟁으로 인한 원가절감 실 패를 경험했던 것과는 달리 많은 수의 LCC들이 급속한 성장을 지속적으로 유지하고 있고, 여전
히 높은 수준의 신규 기재 주문량을 보이고 있으 나, 유럽과 미국에서 점차적으로 노선 집중화 문 제가 나타나고 있으며, $\mathrm{LCC}$ 의 시장 성장이 제한 적이라는 징후들이 조금씩 나타나고 있다(Jaap \& Zuidberg, 2012) 특히 시장이 점차 성숙되어 감에 따라 $\mathrm{LCC}$ 항공서비스 활용 승객의 증가율이 점차 감소되고 있으며(Klophaus et al, 2012) 이 로 인해 비즈니스모델의 변화를 통해 향후 지속 가능 성장을 위한 방안을 신속히 도출하여야 할 것이다. 동북아 국가는 이러한 항공시장의 변화 에 맞춰 LCC 항공사의 활성화 방안 및 경쟁력 향상을 도모할 수 있는 선제적 대응이 필요하다.

\subsection{LCC 비즈니스모델의 성장 한계와 사례}

\subsection{1 노선집중화 문제 및 주요공항의 사용}

$\mathrm{FSC}$ 는 '노선집중화 제조공장(factories to manufacture route density)'으로써 $\mathrm{Hub}$ and Spoke시스템을 사용하지만(Levine, 2009), 고유의 $\mathrm{LCC}$ 비즈니스 모델은 지점 간 운송 시스템을 활 용하고 비용절감에 대한 전사적 역량을 집중함으 로써 동일시간, 동일목적지 및 운항 비용을 충당 할 수 있는 운임의 조합 등으로 노선 집중화 문 제를 제거하기 위한 노력에 초점을 맞추고 있다. 그러나 수익성을 증대하기 위해서는 $\mathrm{O} \& \mathrm{D}$ 시장 에서 최소한도 규모의 $\mathrm{O} \& \mathrm{D}$ 수요를 필요로 한 다. 따라서 지점간 운송을 특징으로 하는 $\mathrm{LCC}$ 비즈니스모델과 관련하여, LCC들은 주요 공항 (Primary Airport)들보다는 도심에서 보통 멀리 떨어져 있는 2차 공항(Secondary Airport)에 초 점을 맞추고 있다. (Franke, 2004) 특히 LCC는 2 차 공항을 활용하여 단순하고 이해하기 쉬운 가 격구조 및 기획성 가격정책으로 저가 노선을 제 공하면서 비용절감을 위해 노력하여 왔으며, 빠 른 수준의 턴어라운드시간(turn-around time)을 유지하여 왔다. 그러나 원거리에 위치한 2차 공 항을 오가는 데 있어 많은 시간이 소요되므로, 시간에 매우 큰 효익을 두는 비즈니스 승객들에 게는 LCC의 서비스가 매력적으로 보이지 않을 수 있다. 그러므로 LCC들은 보다 넓은 시장에서 항공 운임에 민감한 충분한 수의 여행객들을 유 인하기 위해 반드시 저가운임을 제공해야 하지만 (Pantazis, 2006), LCC의 네트워크를 제공하는 2 차 공항들의 지리적 접근성 문제를 함께 고려할 필요가 있다. 물론 주요 노선 증가가 이루어질 경우 노선의 영업 지역 중복 문제가 유발될 수 있다. 즉 근접거리의 공항에서 제공되는 동일한 
목적지의 노선은 수익성 감소를 유발시킬 수 있 고, 미래 성장을 둔화시킬 수 있는 것이 다.(Levine, 2009). 그러나 Southwest의 경우 초 기 성장 단계에서 2차 공항 전략을 따르기는 했 지만, 현재 비즈니스 모델을 변화시켜 주요 공항 에 취항을 하고 있고 유럽 LCC 시장에서 Ryanair만이 유일하게 2차 공항 전략을 고수한 반면, easyJet 또한 유럽 국가들 사이에서 주요 노선들에 초점을 맞추고 있다.

\subsection{2 노선 선택 및 운항횟수}

세계 주요 $\mathrm{LCC}$ 의 평균 주간 운항횟수는 전반 적으로 감소하고 있는데 이는 <Fig 1>을 통해서 확인할 수 있다. 이러한 현상은 노선 집중화에 따 른 문제를 해결하기 위한 방안으로 비즈니스모델의 변 화가 일어나는 것이라고 할 수 있다.

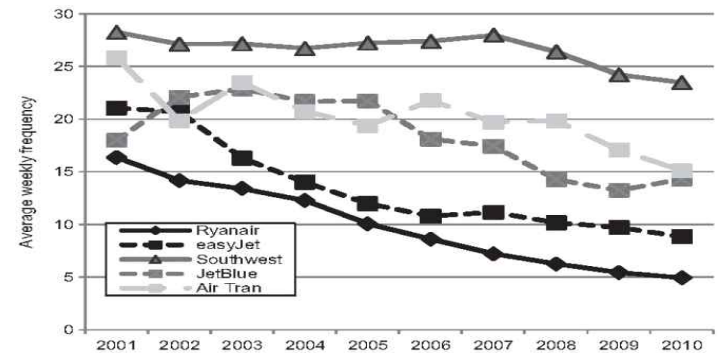

Fig. $1 \mathrm{LCC}$ 의 평균 주간 운항횟수 자료: Jaap G. \& Zuidberg(2012)

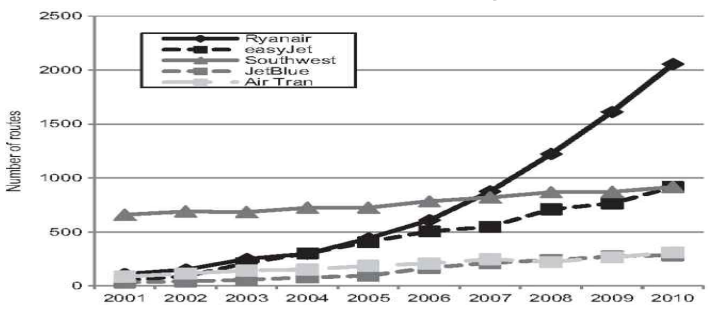

Fig. 2 LCC의 운항 노선 수

자료: Jaap G. \& Zuidberg(2012)

또한 <Fig 2>에서 나타났듯이, 2001년과 2010 년 사이 취항한 노선수와 관련하여 Ryanair의 노 선수가 기하급수적으로 증가추이를 보이는 것 또 한 수요가 낮은 노선에서의 노선 개시가 이루어 지고 있음을 의미하며, 이는 이미 포화되고 있는 시장과 향후 발생 가능한 노선 집중화 문제와 관 련이 있다고 볼 수 있다.

Ryanair의 노선추이는 다른 LCC들과 확연히 다르며, 특히 Southwest의 노선 전략과는 상당히 대조적이라고 할 수 있는데, 그 이유는 최근 몇 년 동안 Ryanair가 노선 수를 상당히 늘려 왔기
때문이다. 그러나 노선 수의 증가로 인해 발생하 는 노선 집중화 제약들은 더욱 더 한계를 나타 낼 것으로 보인다. Ryanair가 최근에 발표한 계 획들을 살펴보면, 낮은 수익성을 보이는 2차 공 항 노선을 주요 공항들로 이전하고 있는데 이처 럼 Ryanair는 향후 더욱 큰 성장을 이루기 위해 궁극적으로 주요 공항들에 집중할 것이고, 아마 도 그 결과, easyJet과 직접적으로 경쟁할 것이 다. 그 외에도 Southwest가 허브의 노선을 증가 시킨 결과와 노선집중화 문제를 연계하여 볼 수 있다.

\subsubsection{LCC 허브화}

$\mathrm{LCC}$ 가 주요 공항에 초점을 맞추는 이유는 노 선 집중화에 따른 문제를 해결하기 위함으로 이 는 랜덤 연결 시스템(random connect system)이 추가적인 항공 교통량을 상승시킬 수 있는 기회 를 제공하기 때문이다. 기존 연구에 따르면, Ryanair 승객들의 $17.2 \%$ 가 런던 스탠스테드 (London Stansted) 공항에서 다른 연결편으로 환 승을 하고, 이들 중 대부분은 Ryanair를 이용한 것으로 나타났다(O'connell \& Williams, 2005). $\mathrm{LCC}$ 와 허브 항공사 간 랜덤 연결 시스템은 허브 공항에서의 $\mathrm{LCC}$ 노선에게 상당한 지선(feeder) 수요로 나타날 수도 있으며, 허브 공항에서 LCC 와 FSC 사이의 제휴를 통해 허브와 관련된 비용 을 유발하지 않는다면 더욱더 크게 시장 수요 확 장을 활성화시킬 수 있을 것이다. WestJet과 Air France-KLM이나 JetBlue와 Lufthansa, Vueling과 Iberia, Jetstar Airways와 American Airlines와 같이 주요 허브들에서 LCC(LCC feeders)와 FSC (혹은 네트워크 항공사) 간의 code-share 협정을 맺는 것도 이러한 허브화의 주요 사례라고 할 수 있다. 특히, 공항에서 LCCT(Low Cost Carrier Terminal) 건설을 추진하는 경우, 이러한 LCC 비즈니스모델을 살펴보아야 할 것이다. <Table 2>는 Southwest가 이미 허브화 과정에서 상당히 많은 발전 단계들을 밟아 왔음을 보여준다. Southwest는 지점간 운송 시스템을 통해 LCC가 가지는 노선 집중화 문제를 부분적으로 해결하기 위한 노력을 기울이고 있다. 이외에 Ryanair는 인수합병의 방법과 자체적인 성장을 통해 사업을 확대시키려고 하는 시도를 Southwest 보다 먼저 시행하였고, 규모가 큰 항공기로 장거리 운항과 저가 유럽 항로들을 운항하고 있는 하이브리드 항공사인 Aer Lingus의 인수를 원하고 있다. 그 러나 유럽의 경쟁 관계자들은, 인수합병으로 인 
하여 Ryanair가 Dublin 시장에서 지배적인 위치 에 오를 수도 있다는 이유로 Ryanair의 Aer Lingus인수를 부결하였다.

Table 2. Southwest 허브화 지표

\begin{tabular}{|c|c|c|}
\hline $\begin{array}{c}\text { Southwest 이용 } \\
\text { 공항 }\end{array}$ & 타 지역 승객 & $\begin{array}{l}\text { 타 지역 } \\
\text { 승객 비중 }\end{array}$ \\
\hline $\begin{array}{c}\text { Chicago Midway } \\
\text { (MDW) }\end{array}$ & $1,446,217$ & $43.2 \%$ \\
\hline $\begin{array}{c}\text { Houston Hobby } \\
(\mathrm{HOU})\end{array}$ & 731,461 & $37.0 \%$ \\
\hline Baltimore (BWI) & 906,573 & $36.6 \%$ \\
\hline Nashville (BNA) & 422,578 & $35.8 \%$ \\
\hline $\begin{array}{c}\text { Dallas Love Field } \\
\text { (DAL) }\end{array}$ & 625,128 & $33.4 \%$ \\
\hline Denver (DEN) & 645,809 & $31.9 \%$ \\
\hline Saint Louis (STL) & 341,286 & $30.2 \%$ \\
\hline Phoenix (PHX) & 860,513 & $28.8 \%$ \\
\hline Las Vegas (LAS) & $1,060,372$ & $27.9 \%$ \\
\hline Kansas City (MCl) & 211,382 & $20.9 \%$ \\
\hline 계 & $7,251,319$ & $33.2 \%$ \\
\hline
\end{tabular}

*자료: Boyd Group International, 2010

\subsection{4 운항거리 증가}

유럽 LCC시장에서 2001년과 2010년 사이의 평 균 운항거리와 관련하여 easyJet의 경우 $40 \%$ 증 가, Ryanair의 경우 $75 \%$ 증가 등 상당한 증가추 이를 보였는데 이러한 증가추이는 아래의 <Fig $3>$ 에서도 확인할 수 있다. 신규 노선 개발에 따 른 이러한 운항거리의 증가는 향후 노선 집중화 문제들로 인한 문제점을 해결하기 위해 이루어지 는 LCC 비즈니스모델의 변화모습 중 하나라고 할 수 있을 것이다.

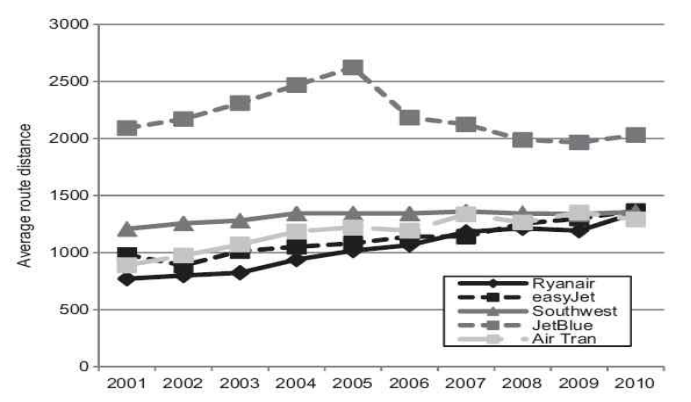

Fig 3. LCC의 평균운항거리 *자료: Jaap G. \& Zuidberg(2012)

특히, 운항 거리가 증가함에 따라 노선 집중화
로 인한 문제가 더욱 부각되어 가고 있으며 운항 거리가 길수록 공항과 영업 지역은 더욱 넓어질 수밖에 없다. 그러나, 최근 연구에서 연결편이 없 는 장거리 지점간 운송은 지속 가능한 비즈니스 모델에서 오히려 좋은 선택이 아닌 것으로 나타 났고(Wensveen \& Leick, 2009), 이러한 결과로 인해 향후 전세계 LCC들 사이에서도 제휴와 협 약의 필요성이 제기될 수밖에 없을 것으로 보인 다. LCC와 LCC, LCC와 FSC 사이의 인터라인 (interlining)과 상용고객우대제도와 같은 협약을 통해 유연한 동맹체가 형성된다면, 장거리 지점 간 운송 시스템도 수익성을 발생시킬 것이다. 그 럼에도 불구하고, 장거리 지점간 운송에서는 항 공기 가동률, 좌석 피치 등과 같이 단거리 저비 용 모델의 장점들 중 일부는 달성할 수 없을 것 이다.(Morrell, 2008). 특히 단거리 노선에서의 비 용 효익은 $50 \%$ 이상인 반면, 장거리 노선에 대 한 기내 무료서비스 제한과 같은 운영의 상대적 비용 효익은 $20 \%$ 에 불과하다는 연구결과가 이를 잘 보여준다.(Francis et al, 2007). 따라서 LCC 관련 장거리 저비용 운송 모델에 부여하는 가장 큰 과제는 부가 수익원의 개발이라고 할 수 있으 며, 부가 수익원의 영향력은 지속적으로 증가할 것이다(Daft \& Albers, 2010).

\subsection{5 부가 수익 확대}

$\mathrm{LCC}$ 비즈니스 모델의 분석은 통상적으로 비용 구조에 초점을 맞추고 있으나, LCC 비즈니스 모 델은 수익 구조를 이루는 부가 수익(Ancillary Revenue)에서도 명확하게 특징이 나타난다고 할 수 있다. 기존 FSC가 항공 서비스에 대한 모든 비용을 포괄하여 운임을 책정하는 반면, LCC는 개별 서비스에 대한 별도의 운임을 책정함으로써 낮은 항공 운임을 제공하여 가격에 민감한 승객 들을 유인할 수 있게 하여 FSC와 더욱 효과적으 로 경쟁할 수 있게 만든다. 특히, 이러한 부가 서 비스에 요금을 부과하는 것은 비용 절감뿐만 아 니라 추가적인 수익을 만들어낸다고 할 수 있다. 이와 관련하여 수익증대방안으로의 옵션 판매방 식에 있어 가산적/감산적 옵션 판매방식에 따라 선택행위가 달라질 수 있다는 연구가 이루어지기 도 하였다. (양석준, 주영혁, 2010) 승객들이 기본 여행 상품에 추가할 수 있는 유료 서비스들은 기 내식 판매, 좌석 우선배정, 우선 탑승, 기내 수하 물, 영화 감상, 인터넷 사용, 베개와 담요 등을 포함하고 있다. 항공사들이 제공할 수 있는 추가 적인 부가 수익은 호텔, 렌터카, 여행자 보험, 제 
휴 신용카드 등과 같은 수수료를 기반으로 하는 상품이다. <Table 3>처럼 부가 수익 비중이 높은 항공사 리스트 10 위 안에는 LCC가 전부 위치하 고 있다. 부가 수익의 매출 비중이 높은 Allegiant는 기본적인 항공 운임에 추가적인 유 료 서비스를 제공함으로써 부가 수익원을 창출하 고 있을 뿐만 아니라, 호텔이나 렌터카 등의 판 매로부터 추가적인 부가 수익을 창출할 수 있는 역량을 키워왔다. Allegiant는 상당부분의 부가 수익을 수수료를 기반으로 한 매출로부터 얻고 있다.(CAPA, 2010a;CAPA, 2010b).

Table 3. 부가수익 비중 1 10위 항공사

\begin{tabular}{|c|c|c|c|}
\hline \multicolumn{2}{|c|}{ Annual Results 2010} & \multicolumn{2}{c|}{ Annual Results 2011} \\
\hline $29.2 \%$ & Allegiant & $29.2 \%$ & Allegiant \\
\hline $22.6 \%$ & Spirit & $23.9 \%$ & Spirit \\
\hline $22.1 \%$ & Ryanair & $22.2 \%$ & Ryanair \\
\hline $21.0 \%$ & Jet2.com & $19.4 \%$ & easyJet \\
\hline $20.5 \%$ & Tiger Airways & $19.4 \%$ & Tiger Airways \\
\hline $19.2 \%$ & easyJet & $18.1 \%$ & Jet2.com \\
\hline $18.7 \%$ & AirAsia & $14.4 \%$ & Aer Lingus \\
\hline $18.1 \%$ & AirAsia X & $13.3 \%$ & Alaska Airlines \\
\hline $15.7 \%$ & Flybe & $13.2 \%$ & Flybe \\
\hline $14.7 \%$ & United & $13.1 \%$ & AirAsia \\
\hline *자료: & IdeaWtinental & Airline Ancillary \\
\hline
\end{tabular}

Revenue and Loyalty Guide for 2011.

\section{3 국내 LCC 현황과 향후 전략적 대 응}

\subsection{1 대륙별 LCC 항공사 현황}

국내 LCC현황을 살펴보기 전에 각 대륙별 LCC항공사의 현황을 살펴보면 <Table 4 >와 같 다. 2012년 6월 현재, 전 세계 50개국에서 126개 의 LCC가 운항을 하고 있으며 지역별 LCC 현 황과 관련하여 가장 많은 LCC 참여가 이루어지 고 있는 지역은 아태지역으로 13 개국 51 개 LCC 가 운항 중에 있다. 이 지역의 높은 활용율은 항 공수요의 급속한 증가와 함께 2000년대부터 시장 에 참여하기 시작한 LCC들이 전반적인 항공 네 트워크 및 공급력 확대에 비중을 높이고 있기 때 문이라고 할 수 있을 것이다. 또한 아태지역에서 의 주요FSC와 $\mathrm{LCC}$ 자회사의 구성은 <Table 5> 와 같다.
Table 4. 지역별 LCC 항공사 현황 (2012. 6 기준)

\begin{tabular}{|c|c|c|c|c|c|}
\hline 북미 & 남미 & 유럽 & 아태지역 & 중동 & 아프리카 \\
\hline 2개국 & $\begin{array}{c}4 \text { 개국 } \\
\text { 12개 }\end{array}$ & $\begin{array}{c}\text { 23개개 } \\
39 \text { 개 }\end{array}$ & $\begin{array}{c}13 \text { 개국 } \\
51 \text { 개 }\end{array}$ & $\begin{array}{c}\text { 3개국 } \\
4 \text { 개 }\end{array}$ & $\begin{array}{c}5 \text { 개국 } \\
11 \text { 개 }\end{array}$ \\
& & & & & \\
\hline
\end{tabular}

Table 5. 아시아-태평양 지역 FSC와 LCC 자회사

\begin{tabular}{|c|c|}
\hline $\begin{array}{c}\text { 기존 } \\
\text { 항공사(FSC) }\end{array}$ & 자회사(LCC) (취합(예정)지) \\
\hline Qantas & $\begin{array}{l}\text { Jetstar(호주), Jetstar Aisa(싱가포르), } \\
\text { Jetstar Pacific(베 트남), } \\
\text { Jetstar Indonesia(인도네시 아), } \\
\text { Jetstar Philippines(필리핀), } \\
\text { Jetstar Japan(일본) }\end{array}$ \\
\hline $\begin{array}{c}\text { Singapore } \\
\text { Airlines }\end{array}$ & $\begin{array}{l}\text { Scoot 국제선(Iong-haul), Sillk Air(국제선), } \\
\text { Tiger Airways Australia(국제선) } \\
\text { Tiger Airways Indonesia(인도네시아), } \\
\text { Tiger-SEAir(필리핀) }\end{array}$ \\
\hline Korean Air & $\operatorname{Jin} \operatorname{Air}($ 한국) \\
\hline Asiana & Air Busan(한국) \\
\hline ANA & Peach(일본), AirAsia Japan(일본) \\
\hline Thai Airwys & $\begin{array}{l}\text { Nok Air(작국 국내선), Thai Tiger[Tiger } \\
\text { Airways 합작], Thai Smile[LCC 사업부 }]\end{array}$ \\
\hline
\end{tabular}

presentation, Brendan Sobie'.

\subsection{2 국내 LCC 항공사 현황}

우리나라는 제주항공(Jeju Air), 진에어, 에어부 산, 이스타항공, 티웨이항공 등 5개의 $\mathrm{LCC}$ 가 활 발히 운항 중에 있으며, 국내노선을 기반으로 국 제노선에도 공격적으로 취항하면서 높은 성장세 를 보이고 있다.

국내저비용항공사의 현황은 <Table 6>과 같다.

Table 6. 국내 저비용 항공사 현황

\begin{tabular}{|c|c|c|c|c|c|}
\hline 구 분 & $\begin{array}{c}\text { 제 주 } \\
\text { 항공 }\end{array}$ & 진에어 & $\begin{array}{c}\text { 에어 } \\
\text { 부산 }\end{array}$ & $\begin{array}{c}\text { 이스타 } \\
\text { 항공 }\end{array}$ & $\begin{array}{c}\text { 티웨이 } \\
\text { 항공 }\end{array}$ \\
\hline $\begin{array}{c}\text { 자본금 } \\
1,100 \text { 억원 }\end{array}$ & 270 억원 & 500억원 & 278억원 & 207억원 \\
\hline $\begin{array}{c}\text { 항공기 } \\
\text { 보유 }\end{array}$ & 11 대 & 8대 & 8대 & 8대 & 5대 \\
\hline $\begin{array}{c}\text { 노선 } \\
\text { (수) }\end{array}$ & 14 노선 & 11노선 & 8노선 & 5노선 & 3노선 \\
\hline $\begin{array}{c}\text { 운항 } \\
\text { 횟수 }\end{array}$ & 주93회 & 주51회 & 주44회 & 주35회 & 주25회 \\
\hline
\end{tabular}


저비용항공사 운송실적에 있어서 <Fig $4>$ 와 같이 인천공항 내 저비용항공사의 2012년 운항편 수 실적은 월별로 점차 증가하고 있으며, 2013년 5 월 현재에도 12 년 동월 대비 높은 수치를 보이 고 있음을 알 수 있다. 또한 <Fig 5>에서처럼 $\mathrm{LCC}$ 의 국제선 여객수 측면에서도 비슷한 추이를 보이고 있는 것을 알 수 있다. 그리고 LCC의 성 장세가 지속되어 2020년에 만약 LCC관련 여객처 리능력이 1000만명이상이 되면, 국내 수익구조에 영향력을 미칠 것으로 볼 수 있다.(김규상, 2012)

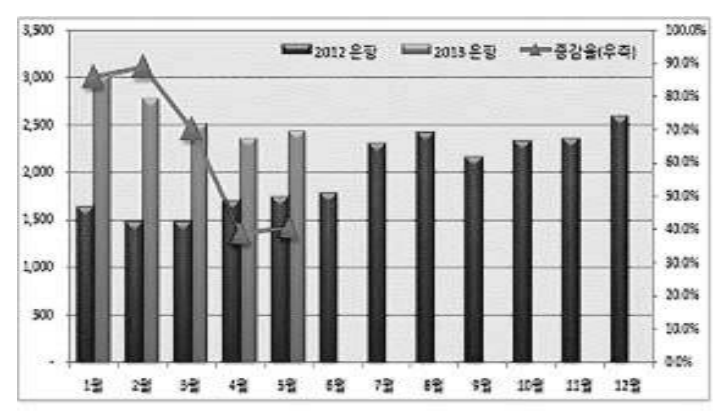

Fig 4. 인천공항 내 저비용항공사 국제선운송실적 운항(편)

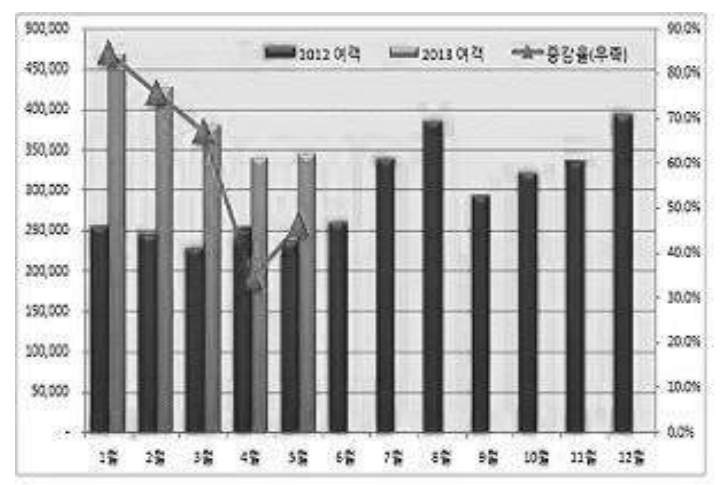

Fig 5. 인천공항 내 저비용항공사 국제선운송실적 여객(명)

국내 LCC항공사 현황과 관련하여 2010년 기준 티웨이항공(T'way Air)을 제외한 4개의 LCC 모 두, 매출액 약 1,000 억원이상을 달성하였고, 2011 년에는 제주항공, 진에어(Jin Air), 에어부산(Air Busan)이 흑자를 달성하여 경영 안정화를 도모 하고 있다. 기존항공사의 자회사 형태가 아닌 독 립적인 LCC의 형태로 운영중인 제주항공은 국내 $\mathrm{LCC}$ 최초로 매출액 약 2,000억원을 돌파하는 동 시에 처음으로 흑자로 돌아섰다. 이와 함께 다른 LCC들도 차별화된 국제노선으로 신규시장을 개 척하고 있다. 이러한 국내 $\mathrm{LCC}$ 의 지속적인 성장
과 함께 최근 중국 및 일본 $\mathrm{LCC}$ 의 시장 진출로 인한 새로운 환경변화에 대비하기 위해 국내 $\mathrm{LCC}$ 의 경쟁력 제고방안과 정책적 지원마련이 필 요할 것으로 보인다. <Table 7>을 통해 LCC의 국내 정규노선별 추이를 살펴보면 군산-제주 노 선(52.5 $\rightarrow 51.9 \%)$ 을 제외한 모든 노선이 상승세를 보이는 가운데, 김포-제주 $(56 \%)$, 김해-제주 $(66 \%)$, 군산-제주 $(51.9 \%)$ 등 3 개 노선은 ' 11 년에 이어 ' 12 년에도 $50 \%$ 이상의 시장점유율을 이루었음을 알 수 있다.

국제노선의 경우 국적 저비용항공사의 시장점 유율은 ' 11 년 $4.3 \%$ 에서 ' 12 년 $7.5 \%$ 로 증가하였으 며, 저비용항공사가 10 만 명 이상 수송한 노선들 가운데 <Table 8 >처럼 김포-오사카 $(14.5 \rightarrow 14.4 \%)$, 김해-오사카 $(30.5 \% \rightarrow 28.5 \%)$ 를 제외한 모든 노선 의 점유율이 증가한 것으로 나타났다.

Table 7. 국내 정규노선 실적 현황

\begin{tabular}{|c|c|c|c|c|c|c|}
\hline \multirow[b]{2}{*}{ 구분 } & \multicolumn{3}{|c|}{ 2011년 } & \multicolumn{3}{|c|}{ 2012년 } \\
\hline & $\begin{array}{c}\text { 대형사 } \\
\text { (명) }\end{array}$ & $\begin{array}{c}\text { 저비용 } \\
\text { (명) }\end{array}$ & $\begin{array}{c}\text { 저비용 } \\
\text { 점 유율 } \\
(\%)\end{array}$ & $\begin{array}{c}\text { 대형사 } \\
\text { (명) }\end{array}$ & $\begin{array}{c}\text { 저비용 } \\
\text { (명) }\end{array}$ & $\begin{array}{c}\text { 저비용 } \\
\text { 점 유율 } \\
(\%)\end{array}$ \\
\hline 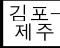 & $4,767,083$ & $5,540,448$ & 53.8 & $4,854,140$ & $6,184,931$ & 56.0 \\
\hline \begin{tabular}{|l} 
김해- \\
제주
\end{tabular} & 999,906 & $1,590,068$ & 61.4 & 904,976 & $1,759,591$ & 66.0 \\
\hline \begin{tabular}{|l} 
김폼- \\
해해
\end{tabular} & $1,296,375$ & $1,022,840$ & 44.1 & $1,195,354$ & 971,899 & 44.8 \\
\hline $\begin{array}{l}\text { 첮줒- } \\
\text { 제주 }\end{array}$ & 734,179 & 437,044 & 37.3 & 685,991 & 461,062 & 40.2 \\
\hline \begin{tabular}{|l} 
군산- \\
체주
\end{tabular} & 80,276 & 88,844 & 52.5 & 75,909 & 81,850 & 51.9 \\
\hline
\end{tabular}

Table 8. 주요 국제 정규노선 실적 현황

\begin{tabular}{|c|c|c|c|c|c|c|c|c|}
\hline \multirow[b]{2}{*}{$\begin{array}{l}\text { 준요 } \\
\text { 노선 }\end{array}$} & \multicolumn{4}{|c|}{ 2011년 } & \multicolumn{4}{|c|}{ 2012년 } \\
\hline & 대형사 & 저비용 & 외항사 & \begin{tabular}{|l} 
LCC \\
비율 \\
$(\%)$ \\
\end{tabular} & 대형사 & 저비용 & 외항사 & $\begin{array}{l}\text { LCC } \\
\text { 비율 } \\
(\%)\end{array}$ \\
\hline $\begin{array}{l}\text { 입청- } \\
\text { 옥 }\end{array}$ & 743,163 & २28,896 & 70,164 & 13.1 & 912,412 & 474,388 & 701,701 & 22.7 \\
\hline 인처사사 & 824,431 & 115,797 &, 202 & 11.2 & 871,992 & 2२2,582 & 252,690 & 16.5 \\
\hline 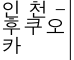 & 765,966 & 4,132 & 0 & 0.5 & 780,008 & 222,165 & 0 & 22.2 \\
\hline 인첳겋ㅇ & $1,037,425$ & 112,340 & 949,558 & 5.4 & $1,185,851$ & 192,303 & 989,152 & 8.1 \\
\hline \begin{tabular}{|l|} 
인천- \\
部
\end{tabular} & 196,851 & 107,688 & 2747 & 35.0 & 230,483 & 154,089 & 0 & 40.1 \\
\hline 김포가카 & 463,856 & 113,812 & 208,352 & 14.5 & 482,640 & 114,396 & 198,963 & 14.4 \\
\hline $\begin{array}{l}\text { 제ㅈㅜㅜ- } \\
\text { 푸동 }\end{array}$ & 0 & 417 & 7,965 & $39 . C$ & 0 & \begin{tabular}{|l}
110,390 \\
\end{tabular} & 81,882 & 57.4 \\
\hline $\begin{array}{c}\text { 깉해- } \\
\text { 이 } \\
\text { 에 }\end{array}$ & 0 & ,967, & 41,683 & 67.1 & 0 & 105,951 & 45,693 & 69.9 \\
\hline $\begin{array}{l}\text { 김해- } \\
\text { 소사카 }\end{array}$ & 2२5,471 & 99,244 & 432 & 30.5 & 264,598 & 105,524 & 0 & 28.5 \\
\hline 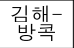 & 155,023 & 35,009 & 5,112 & 14.2 & 156,015 & 103,446 & 75,600 & 30.9 \\
\hline 임천- & 656,632 & 79,025 & 516,372 & 6.3 & 629,78 & 102,843 & 549,240 & 8.0 \\
\hline 김해해 & 1,764 & 90,800 & 0 & 27.9 & 243,183 & 101,967 & 0 & 29.5 \\
\hline
\end{tabular}

* ' 12 년 기준 저비용항공사가 10 만명이상 수송한 노선 대상 
또한 <Table 8>에서처럼 저비용항공사가 높은 점유율을 보인 노선은 김해-타이페이 $(69.9 \%)$, 제 주-푸동 $(57.4 \%)$ 노선 순으로 나타났으며, 인천-후 쿠오카 $(0.5 \longrightarrow 22.2 \%)$, 제주-푸동 $(39 \rightarrow 57.4 \%)$, 김해방콕 $(14.2 \rightarrow 30.9 \%)$ 노선은 가장 높은 점유율 상승 세를 보였다. 2013년에는 외국계 저비용항공사의 취항 확대로 인한 경쟁 심화 등 국적 저비용항공 사 성장에 있어 부정적인 요인도 존재하나, 해외 여행객 수요의 지속적인 증대와 국적 저비용항공 사들의 항공기 추가도입 및 국제노선 확대 등에 따라 저비용항공사의 성장세가 지속될 전망이다. 2011년 말 기준으로 국내선은 $29.4 \%$, 국제선은 $5.0 \%$ 로 LCC가 먼저 발전한 미국이나 유럽보다 낮은 비중을 차지하고 있으나, 향후 발전 잠재력 을 가지고 있다고 볼 수 있고 특히, 제주-김포 노선의 경우, 시장 점유율이 $50 \%$ 이상을 기록하 고 있는 것으로 비추어 볼 때, 단거리 항공서비 스 이용객은 향후 급증하리라 판단되며 최근 국 외LCC가 적극적으로 한국시장을 진입하는 계기 가 될 것으로 보인다.

\subsection{3 국내 $\mathrm{LCC}$ 산업 및 $\mathrm{LCC}$ 의 전략 방향}

국내 LCC는 독립적인 LCC와 FSC의 자회사로 구분 지어지며, 각 항공사의 사정에 따라 고유의 $\mathrm{LCC}$ 비즈니스 모델을 변경하는 것이 매우 중요 하다. 특히, 최근 국내 항공시장 수요 증가폭이 둔화되고 주변국가, 특히 중국과의 항공협정에 따른 개방화가 늦어지면서 LCC는 앞서 살펴본 노선 집중화 문제가 발생하고 있고 이를 해결하 기 위해 부정기편의 확대, 노선 조정 등 각각의 LCC 비즈니스 모델을 변화시켜 지속가능 전략을 추진해야 한다. 이와 함께 기존 $\mathrm{FSC}$ 의 견제, $\mathrm{LCC}$ 간 노선 중복, 한국의 $\mathrm{O \& D}$ 시장 수요보다 많은 경쟁업체수 등 $\mathrm{LCC}$ 의 경쟁이 더욱 치열해 질 것으로 보이므로 앞에서 살펴본 유럽과 미국 의 사례를 면밀히 살펴보고 이를 바탕으로 $\mathrm{LCC}$ 비즈니스 모델을 확실하게 정립, 명확한 고유의 기업 방향을 설정할 필요가 있다. 특히 이는 국 내 LCC산업의 구조조정 (국내 항공사간 $\mathrm{M} \& \mathrm{~A}$ 포함), 노선 운영의 탄력성 확보, 주요 공항 사 용, 해외 FSC와의 제휴, 제4수요와 제6수요 개발, 부가수익원확대, 인센티브 개선 등의 측면에서 살펴볼 수 있을 것이다. 국가적으로 국내 LCC의 노선 중복에 따른 출혈 경쟁은 국내 LCC 산업을 전반적으로 저해할 수 있다. 무엇보다도 다수의 $\mathrm{LCC}$ 가 난립함으로서 발생하는 노선의 쏠림 현상
이 있는 가운데 시장에서 도태되어 가고 있는 기 업에 대해서는 다소 강제적인 구조조정을 통해서 라도 정리가 필요할 것으로 보이며, 이는 시장의 공정한 경쟁을 위해 필요할 뿐만 아니라 국외 $\mathrm{LCC}$ 의 본격적인 한국 시장 진입 전에 이루어져 야만 다국적 $\mathrm{LCC}$ 와 본격적으로 경쟁할 수 있는 환경이 조성될 수 있을 것이다. LCC는 개별 기 업으로서 노선 시장을 효율적으로 예측 및 분석 을 하고, 기존 노선 수요에서 탄력적으로 운항횟 수를 조정하며 신규 노선을 지속적으로 개발하여 새로운 항공 수요를 창출하는 노력을 기울여야만 한다. 앞의 사례에서 노선 집중화로 인한 문제를 랜덤 연결 시스템을 활용하여 대응한 사례와 같 이 국내 LCC도 주요 공항을 중심으로 환승 수요 를 발생시킬 수 있는 시스템을 갖추고 있어야 할 것이다. 또한 국내 $\mathrm{LCC}$ 는 해외 FSC의 지선 (feeder) 역할을 통해 수요를 확대시킬 수 있을 것이다. 그러므로 자체적으로 제 4 수요에 해당하 는 In-bound 고객을 유치하는 것은 물론 타국에 서 발생한 수요를 해당 항공사가 제공하지 않는 지선 노선을 운영하여 제6수요를 개발하는 지속 적인 노력과 이러한 수요를 유지해줄 수 있는 파 트너 항공사와의 제휴를 통해 확장, 상호간의 이 익을 도모할 수 있어야 한다. 또한 국내 소비자 들의 특성으로 인하여 국내 LCC 비즈니스 모델 에는 유료 서비스에 대한 구색이 잘 갖추어 있지 않은 것이 사실이지만, 향후에는 유료 서비스 도 입에 따라 기본 운임과 부가 수익원을 구분하여 야 할 것이다. 앞에서 살펴보았듯이 고객은 불투 명한 선택 운임보다는 기본 운임에 대해 더욱 민 감하기 때문에 향후 한국 소비자들에게 부가 수 익을 창출할 수 있는 새로운 운임 체계가 필요하 며, 부가 수익을 극대화 시킬 수 있는 서비스 아 이템 발굴이 필요하다. 이와 함께 LCC의 확장이 이루어지기 위해서는 제도적인 뒷받침이 선행되 어야 한다. 특히 2009년부터 인천공항에 취항한 국내 저비용항공사는 2011년 10월 기준으로 5\% 정도 시장점유율을 확보하고 있으며 주로 저비용 항공사의 단거리 노선에 대한 Needs가 효과적으 로 반영되지 못하여 왔으므로, 중장기적으로 저 비용항공사의 성장과 인천공항의 허브화 전략의 Alignment를 고려한 인센티브 분석/설계가 면밀 히 이루어질 필요가 있을 것이다. 


\section{III. 결론}

세계 항공운송산업, 특히 미국과 유럽에서 $\mathrm{LCC}$ 의 성장이 굉장히 빠르고 지속적으로 이루어 지고 있으나 점차 노선 집중화 문제 등으로 인해 LCC 비즈니스 모델의 변화가 이루어지고 있다. 미국과 유럽 시장에서 LCC 시장이 포화되고 있 다는 징후는 평균 운항횟수 감소, 평균 노선 거 리의 증가 등을 통해 알 수 있으며 이에 대응하 기 위한 LCC업체의 다양한 전략적 변화는 국내 의 LCC 성장에 있어 매우 중요한 시사점을 제공 해줄 수 있을 것이다. 세계 주요 $\mathrm{LCC}$ 들은 그들 의 LCC 비즈니스 모델을 새로운 환경에 맞춰 변 화시키고 있고, 향후 발생 가능한 문제점에 대해 선제적으로 대응하고 있다. 그러므로 우리나라 LCC도 향후 노선집중화 문제발생시 주요 공항들 을 활용한 허브화, 코드쉐어 체결, 얼라이언스 (Alliance) 가입, 경쟁사 인수합병 등과 같이 LCC 고유의 비즈니스 모델에서 벗어나 미래 성 장을 보장하는 새로운 사업 전략들의 방안을 수 용하여 변화와 혁신을 통해 새로운 성장을 모색 할 수 있어야 할 것이다. 그리고 주요공항 기반 노선의 탄력적인 확장, 제휴를 통한 신규 항공 수요 및 부가 수익 창출 등 변화하는 환경에 적 극 대응할 수 있어야 한다. 또한 저비용항공사를 비롯한 항공산업과 공항산업을 뒷받침할 수 있는 항공정책과 시설 등의 지원이 이루어지고 국가적 차원에서의 항공 및 관광산업 내 정책적 지원과 이해관계자 전체의 협력이 이루어질 때 이러한 LCC 비즈니스 모델 변화가 성공적으로 추진될 수 있을 것이다.

\section{참 고 문 헌}

\section{국 외 문 헌}

[1] Boyd Group International, "Southwest/AirTran Merger. An Independent Metrics Overview," www.aviationplanning.com, 2010

[2] Campbell, A. \& Kingsley, J., "Is there any stopping the low-cost carriers?," Flight international, April, 9. 2002

[3] CAPA, "Low cost airlines in the Asia Pacific region : an exceptional intra-regional traffic growth opportunity." Center for Asia
Pacific Aviation, 2002

[4] CAPA, "Ancillary Revenues to Total USD 23 bn in 2010 and Set to Triple," www.centreforaviation.com, 2010a

[5] CAPA, "European Carriers Now Carry a Third of all Pax. Can Full Service Airlines Confine Damage to Short-haul?," www.centreforaviation.com, 2010b

[6] CAPA, "Centre for Aviation Rankings Tool \& Innovata," 2010

[7] CAPA, "Asian market overview presentation", Brendan Sobie., 2012.

[8] CAPA, "LCC North Asia Report FINAL," 2012.

[9] Daft, J., Albers, S., "A Profitability Analysis of Low Cost Long Haul Flight Operations," Paper presented at the 14th ATRS Conference, Porto, July 2010

[10] Doganis, R., "Flying off Course: Airline Economics and Marketing," Routledge, London, 2010

[11] ELFAA, "Liberalization of European Air Transport: The Benefits of Low Fares Airlines to Consumers," Airports, Regions and the Environment, 2004.

[12] Francis, G., Humphreys, I., Ison, S. \& Aicken, M., "What is next of low cost airlines? : A spartial and temporal comparative study," Journal of Transport Geography, Vol14, 2006, pp83 94.

[13] Francis, G., Dennis, N., Ison, S., Humphreys, I., " The transferability of the low cost model to long-haul airline operations," Tourism Management, Vol. 28(2), 2007, pp391 398.

[14] Franke, M., Competition between network carriers and low-cost carriers retreat battle or breakthrough to new level of efficiency? Journal of Air Transport Management, Vol. 10(1), 2004, pp.15 21.

[15] Franke, M., John, F., “What comes next after recession? Airline industry scenarios and potential end games," Journal of Air Transport Management Vol. 17, 2011, pp.19 26

[16] Garriga,J., "Low-cost a regional affair. Airport Regions Conference Proceedings," 2007 [17] Gittell, D., "The South West Airlines Ways," McGraw-Hill, New York, NY., 2003 
[18] Gui Lohmann, Tay T.R. Koo, "The airline business model spectrum," Journal of Air Transport Management, 2013, Vol.31, pp.7 9

[19] IdeaWorks, "Airline Ancillary Revenue and Loyalty Guide for 2011.", 2011

[20] Jaap G. \& Zuidberg, J. "The growth limits of the low cost carrier model," Journal of Air Transport Management Vol. 21, 2012, pp.17 23.

[21] Klophaus, R, Conrady, R, Fichert, F, "Low cost carriers going hybrid: Evidence from Europe," Journal of Air Transport Management Vol.23, August 2012, pp. 54 58.

[22] Levine, M.E., "Airline Consolidation: How Will it Reshape the Industry? What Does it Mean for Europe?," First annual airneth lecture, Schiphol, March 2009.

[23] Morrell, P., "Can long-haul low cost airlines be successful?," Research in Transportation Economics Vol.24(1), 2008, pp.61 67

[24] O'Connell, J.F., Williams, G., "Passengers' perceptions of low cost airlines and full service carriers: a case study involving Ryanair, Aer Lingus, Air Asia and Malaysian Airlines," Journal of Air Transport Management Vol.11, 2005, pp.259 272.

[25] Pantazis, N., Liefner, I.(2006), "The impact of low cost carriers on catchment areas of established international airports: the case of Hanover Airport," Germany, Journal of Transport Geography, Vol. 14, 2006, pp.265 272.

[26] Sterzenbach, R., Conrady, R., Fichert, F., "Luftverkehr e Betriebswirtschaftliches Lehrund Handbuch," Oldenbourg, München, 2009.

[27] Taneja, N.K., "Looking beyond the Runway: Airlines Innovating with Best Practices while Facing Realities," Ashgate, Farnham, 2010

[28] Thomas, G., "Asia's absent revolution," Air Transport World, Sep, 2002, pp.42 47

[29] Wensveen, J.G., Leick, R., "The long-haul low cost carrier: a unique business model," Journal of Air Transport Management Vol. 15, 2009, pp.127 133.

\section{국 내 문 헌}

[1] 김규상, “저비용항공사 국제선 취항증가와 인 천공항 수익구조의 관계연구," 한국항공대학교 대학원 석사논문, 2012

[2] 김제철, " 21 세기 항공운송 환경변화와 항공정 책 방향(2단계)," KOTI., 2004

[3] 서선, "한국의 국제선 저가 항공사 비즈니스 모델," 대한관광경영학회 제 31 차 정기학술대회 학술연구발표 논문집, 202-205, 2008

[4] 양석준, 주영혁, "저비용 항공사의 옵션 가격 도입 전략에 관한 연구," 한국항공경영학회지, Vol. 8(2), 2010, pp. 73-86

[5] 양용석, "국내 지역기반 저비용항공사의 SWOT분석과 경쟁력 제고 전략," 교통정책연구 제 12 권 제 2 호, 한국교통연구원, 2005

[6] 양용석, "국내 저가항공 산업의 선진화를 위 한 정책적 제언," 항공진흥 2011년 제1호/통권56 호, 2011, pp.173 185

[7] 육진영, “항공운송시장 변화에 따른 저비용항 공사와 인천국제공항의 대응전략," 한국항공대학 교 석사논문, 2012

[8] 이동희, “아시아태평양 항공시장의 동향과 한 국 $\mathrm{LCC}$ 의 경쟁력 강화방안에 관한 탐색적 연 구," 한국항공경영학회지, $\operatorname{Vol} .10(4), 2012$, pp.127 [9] 최경훈, "저가항공사 성공요인에 대한 실증연 구," 한국항공대학교 경영대학원 석사학위논문, 2008

[10] 최휴종, “한국의 저가항공사의 포지셔닝과 마케팅전략," 한국항공경영학회지, 제 8 권 제 1 호, 2010. 3, pp.3 13

[11] 한대로, "국내 저비용항공사의 현황 및 사례 분석을 통한 경쟁력 제고 방안," 한국항공대학교 석사학위논문, 2010 